\title{
Detection of submerged harbour using GEBCO and MBES data, in the offshore region of ancient port city Poompuhar, South India
}

\author{
SM. Ramasamy ${ }^{1 * *}$, J. Saravanavel ${ }^{1}$, K. Palanivel ${ }^{1}$, C. J. Kumanan ${ }^{1}$ and \\ D. Rajasekhar ${ }^{2}$ \\ ${ }^{1}$ Department of Remote Sensing, Bharathidasan University, Tiruchirappalli 620023 , India \\ ${ }^{2}$ National Institute of Ocean Technology, Velacherry-Tambaram Main Road, Pallikaranai, Chennai 600100 , India
}

\begin{abstract}
Similar to several ancient coastal/port cities of the world, the Indian subcontinent too had a number of them. The Poompuhar is one such port city established at the mouth of river Cauvery by the Chola dynasty 2000 years ago according to the literature and history. However, while later archaeological studies indicate its spread $20 \mathrm{~km}$ along the coast and up to $8 \mathrm{~km}$ inside the Bay of Bengal sea, the recent studies indicated its initial establishment over one of the Cauvery's oldest deltas of 11,000-15,000-year-old at $30 \mathrm{~km}$ inside sea and the later shift to the present location. Now, the GEBCO-2019 and MBES based present study revealed the presence of a harbour and related structures in the above delta, resembling 6000-2000year-old harbours of the world and the knowledge of the people in construction technology and marine environment.
\end{abstract}

Keywords: Ancient port city, offshore region, seabed topography, submerged harbour.

ALL over the world, there are many ancient coastal cities with palatial establishments related to the past kingdoms, civilizations and maritime histories. Significant among them, to cite a few, are Baiae, Italy ${ }^{1}$; Pavlopetri, Egypt ${ }^{2}$; Pisa, Tuscany, Italy ${ }^{3}$; Thonis-Heracleion, Egypt ${ }^{4}$; Alexandria, Egypt ${ }^{5,6}$; Atlit-Yam, Israel ${ }^{7}$; Phanagoria, Russia ${ }^{8}$ and Shicheng, China ${ }^{9}$. These cities, established during 1000-8000 years BP, have been the vacation homes for the rich and the ancient harbours, and some were well planned with buildings and roads and also webbed with wharves, etc. Owing to the over $7500 \mathrm{~km}$ long coastline both in its east and west, the Indian subcontinent too was bestowed with a number of ancient ports and coastal cities. Among these, 4000-5000-years-old Dwarka ${ }^{10}$ on the west coast and 2000-years-old Poompuhar ${ }^{11}$ on the east coast of India have remained the leading coastal cities of mythological and maritime importance. Accord-

\footnotetext{
*For correspondence. (e-mail: smrsamy@gmail.com)
}

ing to the Tamil Sangam literature (300 BC-AD 300), this flourishing port city of Poompuhar, having trade links with several far-flung countries, was established around 2000 years ago by the Chola Dynasty (D, Figure 1) at the mouth of River Cauvery along the east coast of Tamil Nadu, India ${ }^{12,13}$. However, around AD 1000 it seems to have suddenly vanished from the maritime history of the world.

Exhaustive narrations on Poompuhar have been made in the Sangam literature-Purananuru, Agananuru, Natrinai, Cilappathikaram, Manimaghalai and Pattinappalai $^{13-15}$. According to Pattinappalai, Poompuhar was a well-planned city with buildings of divergent architecture, reflecting different culture and civilization; social clusters of nativity and also hybrid culture due to intercontinental trade links. Detailed archaeological explorations have been carried out on both land and sea ${ }^{16-19}$, which revealed that Poompuhar has extended $20 \mathrm{~km}$ from Kadaikadu in the north to Tarangambadi in the south along the coast and $3-4 \mathrm{~km}$ in the landward side in the west (Figure 1).

In the seaward side, Poompuhar has extended up to $8-25 \mathrm{~m}$ water depth and $8 \mathrm{~km}$ from the present coast in the Bay of Bengal. The scattered remains found during these explorations were wharves in Melaiyur, Buddha Vihara in Melapperumpallam, wharf in Keezhaiyur, water outlet in Vanagiri, brick structures parallel to the coast, cairn circles, terracotta wells, Yavanar Irukkai (residences of foreigners), settlements of the business community and urn burials in the present-day land region ${ }^{16-19}$; whereas Suryakundam, Somakundam and $U$-shaped structure were located at a depth of 8-25 $\mathrm{m}$ in the sea (Figure $1 d)^{16-20}$.

Except these, no major structures or remains of Poompuhar have been located so far either on land or in the Bay of Bengal. Recent studies carried out using the ocean bathymetry data derived from GEBCO (General Bathymetric Chart of the Oceans) data and the past sea levels have indicated that the shoreline of 20,000 years BP was 25-30 km east of the present-day Poompuhar coast 


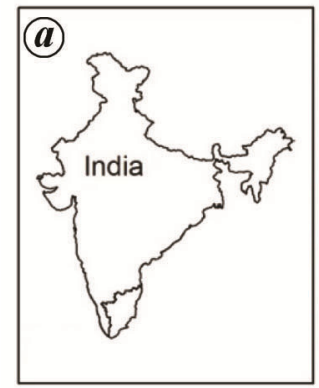

\section{(b)}
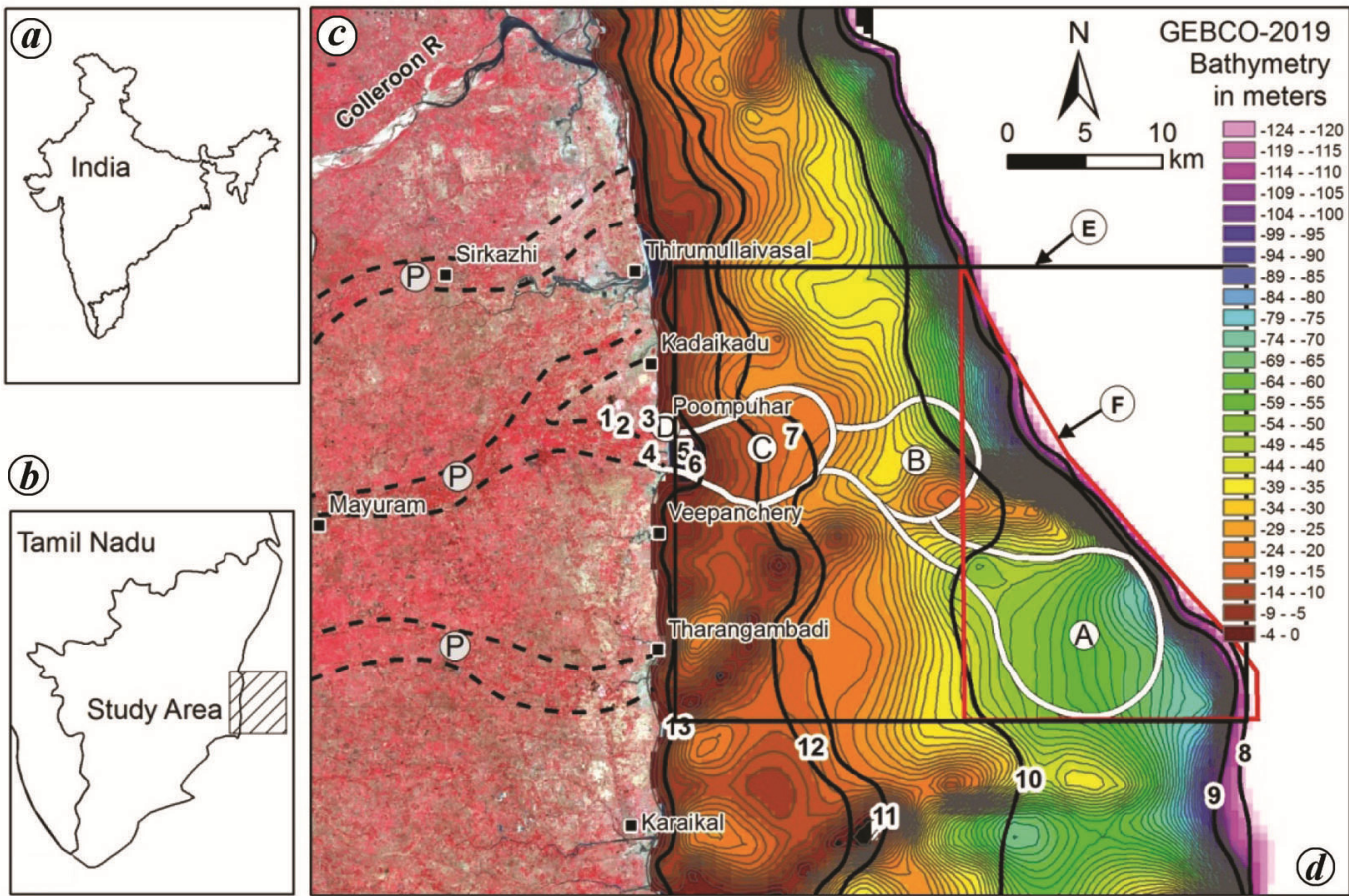

Figure 1. Study area and background details of Poompuhar, Tamil Nadu, India. $\boldsymbol{a}, \boldsymbol{b}$, Key maps. $\boldsymbol{c}$, Land region of Poompuhar shown over IRS LISS IV FCC satellite imagery. $\boldsymbol{d}$, Off-shore region shown over the bathymetry contours and digital elevation model (DEM) derived from GEBCO-2019 data (modified after Ramasamy et al. 2017). (P) old courses of River Cauvery: (1) Melaiyur wharf, (2) Buddha Vihara, (3) Keezhaiyur wharf, (4) Vanagiri water outlet, (5) Surya kundam, (6) Somakundam, (7) $U$-shaped structure. A-C, submerged lobate deltas of River Cauvery where the ancient port city Poompuhar I, II and III might have been located respectively; D, Present location of Poompuhar: Past shorelines during (8) 20,000 years BP at $125 \mathrm{~m}$ depth, (9) 15,000 years BP at 110 m depth, (10) 11,000 years BP at $50 \mathrm{~m}$ depth, (11) 9000 years BP at $25 \mathrm{~m}$ depth, (12) 8000 years BP at $20 \mathrm{~m}$ depth and (13) 7000 years BP at $5 \mathrm{~m}$ depth. E, Area studied using GEBCO-2019-based bathymetry data. F, Area studied using multibeam echo sounder (MBES)-based bathymetry data.

$(8 \text {, Figure } 1 d)^{21}$. River Cauvery flowed over this land and developed two major lobate deltas (A and B, Figure $1 d$ ) 25-30 km from the present coast. Over the oldest delta A, Poompuhar-I might have been established around 11,000-15,000 years BP. Later, it would have shifted in four phases to the present location at the mouth of the Cauvery (D, Figure $1 d$ ) due to continuous sea-level rise from 120 to $5 \mathrm{~m}$ below msl during 20,000-7000 years BP, as observed from the past shorelines (8-13, Figure $1 d$ ) between these periods ${ }^{21,22}$. In continuation with these observations, the present study was carried out to explore the possibilities of submerged structures, if any, between the present coast and delta-A using GEBCO digital elevation model (DEM) and the digitally processed multi-beam echo sounder (MBES) data (Figure 1). This article describes the detection of a few structures related to Poompuhar at the depth of 70-80 $\mathrm{m}$ under the sea in the delta A region.

\section{Methodology}

The methodology involved four sequential steps.

(i) In the first step, the IRS LISS-IV FCC (Indian Remote Sensing Satellite - Linear Self Scanning System False Colour Composite) and the GEBCO data were studied. The IRS FCC data were used to study the western land part of the Poompuhar region (Figure $1 c$ ). The GEBCO 2019 data which provided seabed elevations with a spatial resolution of $500 \mathrm{~m} \times 500 \mathrm{~m}$ were downloaded from its website (https://www.gebco.net), and DEM and seabed topographic contours of $5 \mathrm{~m}$ intervals were generated using ArcGIS (Figure $1 d$ ). From this, the study block of $1200 \mathrm{sq} . \mathrm{km}(40 \times 30 \mathrm{~km}) / 4800$ pixels, covering the present coast in the west and delta- $\mathrm{A}$ in the east was selected (E, Figure 1), for a regional perspective of the seabed topography.

(ii) In step 2, the high-resolution MBES data were studied for an area of $300 \mathrm{sq} \mathrm{km}$ in delta-A/Poompuhar-I region ( $F$, Figure 1) to explore submerged structures, if any. The MBES data that provide seabed elevations, acquired by the National Institute of Ocean Technology, Chennai, with a scan-line interval of $400 \mathrm{~m}$ in the $\mathrm{N}-\mathrm{S}$ direction were collected. They were rasterized to 115,200 pixels of size $50 \mathrm{~m} \times 50 \mathrm{~m}$ for the study area of 300 sq. km. Then the elevations were noted down for each pixel, and DEM and seabed topographic contours of $1 \mathrm{~m}$ interval were generated for the delta-A region using ArcGIS (Figure 2). From the MBES-DEM data and the contours, four anomalies indicating the probable seabed structures in the delta-A region were located (Figure 2). 


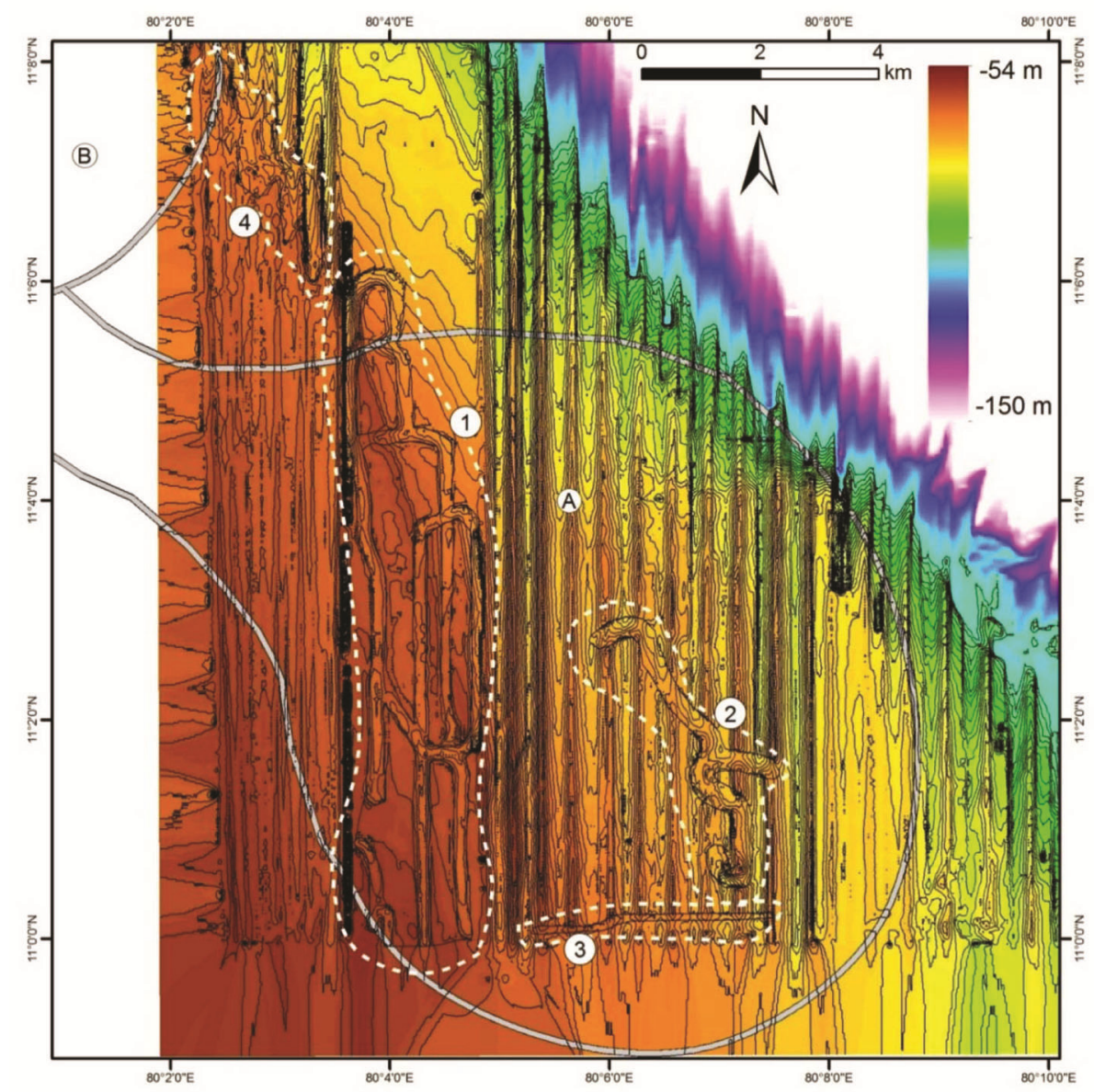

Figure 2. MBES data image. Showing the anomalies (1-4) amidst the seabed contours of delta-A region, 25-30 km inside the Bay of Bengal.

(iii) In step 3, the raster GIS-based seabed topography of the delta-A region (F, Figure 1) derived from MBES data having 115,200 pixels was subjected to various digital image processing techniques after linearly stretching the elevation data of these pixels from 0 to 255 using the algorithm for stretching the satellite multispectral remote sensing data ${ }^{23}$. The image processing techniques used were convolution high-pass filtering $7 \times 7$, Sobel edge detection and texture-based entropy filtering (Figure $3 c$ e) of the ENVI image processing software ${ }^{23}$. These processed images revealed anomalies in four locations (1-4, Figure $3 a$ and $b$ ) in the seabed, coinciding with those detected in the MBES contours shown in Figure 2.

(iv) In step 4, the anomalies detected from the MBESDEM data/contours and the digitally processed outputs were further studied individually in detail by analysing the contour patterns (Figures $4 b$ and $5 b, e, h$ ), shaded relief images (Figure $4 c$ ) and colour-coded DEM (Figure $4 d$ ). The topographic profiles were also drawn across these anomalies to study their morphologies with special reference to the relief variations (Figures $4 e, f, h$ and $5 d$, $g$ and $j$ ). In colour coding, various shades of colours were assigned to different elevations of DEM using the options available with ArcGIS (Figure 2). Similarly, to prepare the shaded relief images from MBES-DEM data, the ArcGIS 3D analyst module was used which flashed a light source from two different elevations and azimuths over the DEM. This in turn generated shadows in the DEM depending upon the elevation of the seabed topography, which exaggerated the relief of the seabed aiding better interpretation of features (Figure $4 c$ ).

Finally all these observed from step- 1 to 4 were integrated together to elucidate the anomalies and identify whether they reflect any structures related to Poompuhar1 in the delta-A region.

\section{Observations}

\section{GEBCO data and delta-C/Poompuhar-III}

The GEBCO-2019-based seabed topography of the region and DEM generated from there reveal one more submerged delta of River Cauvery (C, Figure $1 d$ ) at $30 \mathrm{~m}$ below $\mathrm{msl}$, in addition to the already inferred delta-B at 30-60 $\mathrm{m}$ and delta-A at 55-80 $\mathrm{m}$ below $\mathrm{msl}^{21}$ (Figure 1). 

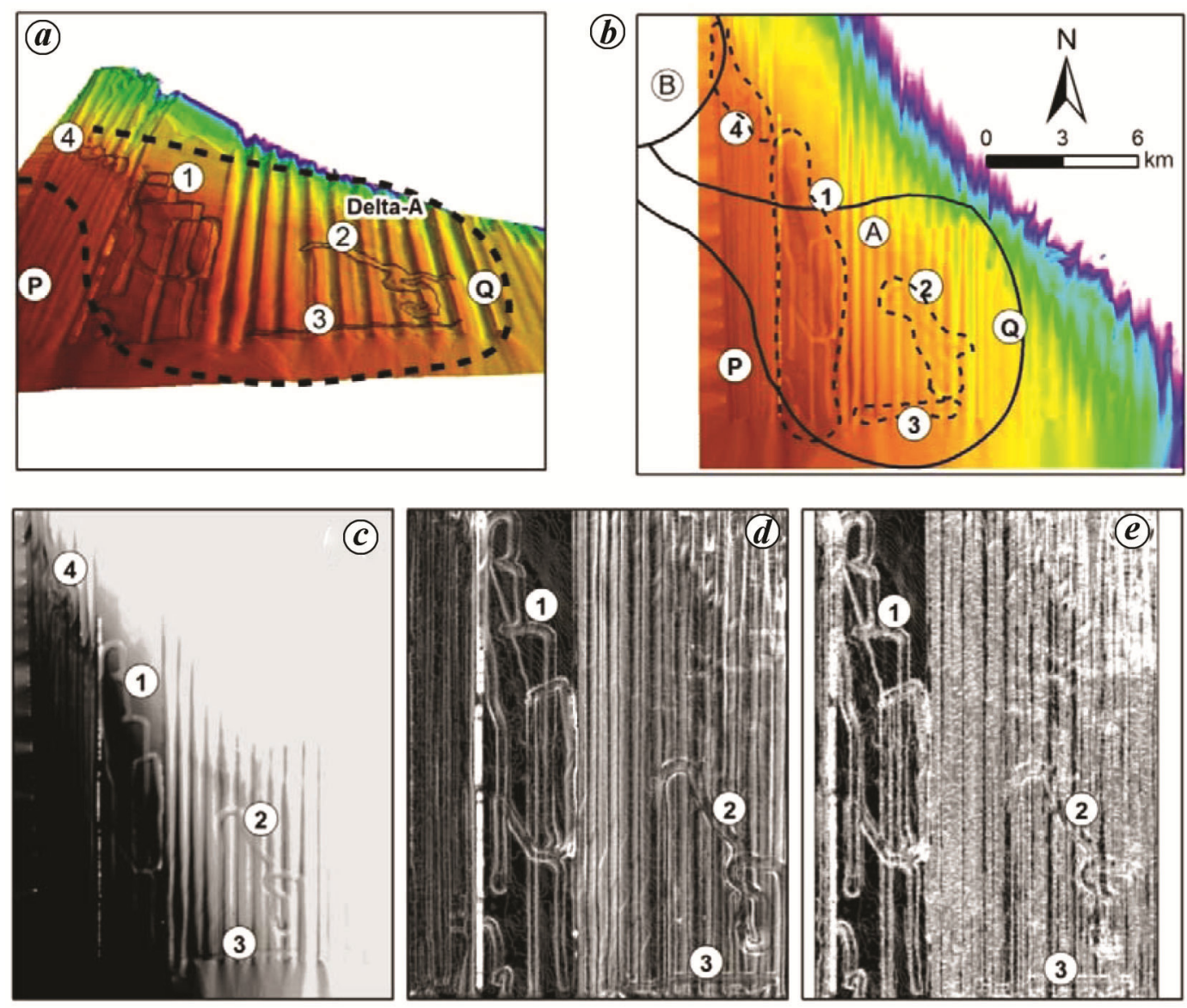

Figure 3. Colour-coded DEM and digitally processed images of MBES data. $\boldsymbol{a}$, Colour-coded MBES-DEM of seabed topography of delta-A region: P, Continental shelf; Q, Continental slope; 1-4, Anomalies seen in seabed topography in colour-coded MBES-DEM data. $\boldsymbol{b}$, Enlarged colour-coded MBES-DEM data of seabed topography showing the anomalies 1-4. $\boldsymbol{c}$, Convolution high-pass filtered $7 \times 7$ image. $\boldsymbol{d}$, Sobel edge detector image. $\boldsymbol{e}$, Texture-based entropy-filtered image.

Earlier studies have observed that Poompuhar-I and II might have been established in delta- $\mathrm{A}$ and $\mathrm{B}$ respectively ${ }^{21}$. In the context of the present inference, Poompuhar III might have been established/reassembled in delta-C, when delta-B was submerged due to the rise in sea level. Features like Suryakundam, Somakundam and $U$-shaped structures earlier reported to be scattered are now seen to fall in the delta-C region (Figure $1 d$ ), which indicates that this might have been the third location of the resettled/reassembled Poompuhar-III. In addition, the regional GEBCO-DEM and the contours have shown two subparallel and curvilinear ridges in the northeast-southwest to east-west directions (5 and 6, Figure 6).

\section{MBES data and other seabed structures}

The enlarged colour-coded MBES DEM data and contours generated on the seabed topography of the delta-A region show flat topography of the continental shelf and low easterly gradient of the continental slope ( $\mathrm{P}$ and $\mathrm{Q}$, Figure 3). Despite noise in the data in the form of $\mathrm{N}-\mathrm{S}$ parallel lines caused due to scanning of the echo sounder, the MBES-DEM data and the contours show discrete anomalies in four locations in the delta-A region (1-4, Figures 2, $3 a$ and 4a). Among these, anomaly no. 1 was observed to show contours with grid pattern, anomaly no. 2 was seen to be a NW-SEoriented, wavy elevated feature, anomaly no. 3 showed E-W sharp linear elevated feature and anomaly no. 4 displayed a wavy NW-SE feature with positive relief (Figure 2).

These anomalies (1-4, Figure 2$)$ were explicitly seen in various digitally processed data (Figure $3 c-e$ ). These anomalies were further studied in detail individually to decipher whether they were related to any structures of the submerged ancient port city of Poompuhar.

Anomaly no. 1: Amidst the otherwise corrugated contours (Figures 2 and $4 \mathrm{~b}$ ), there observed grided contours with squarish, north-south rectangular and trapezohedronic shapes of varying dimensions in the shaded relief 

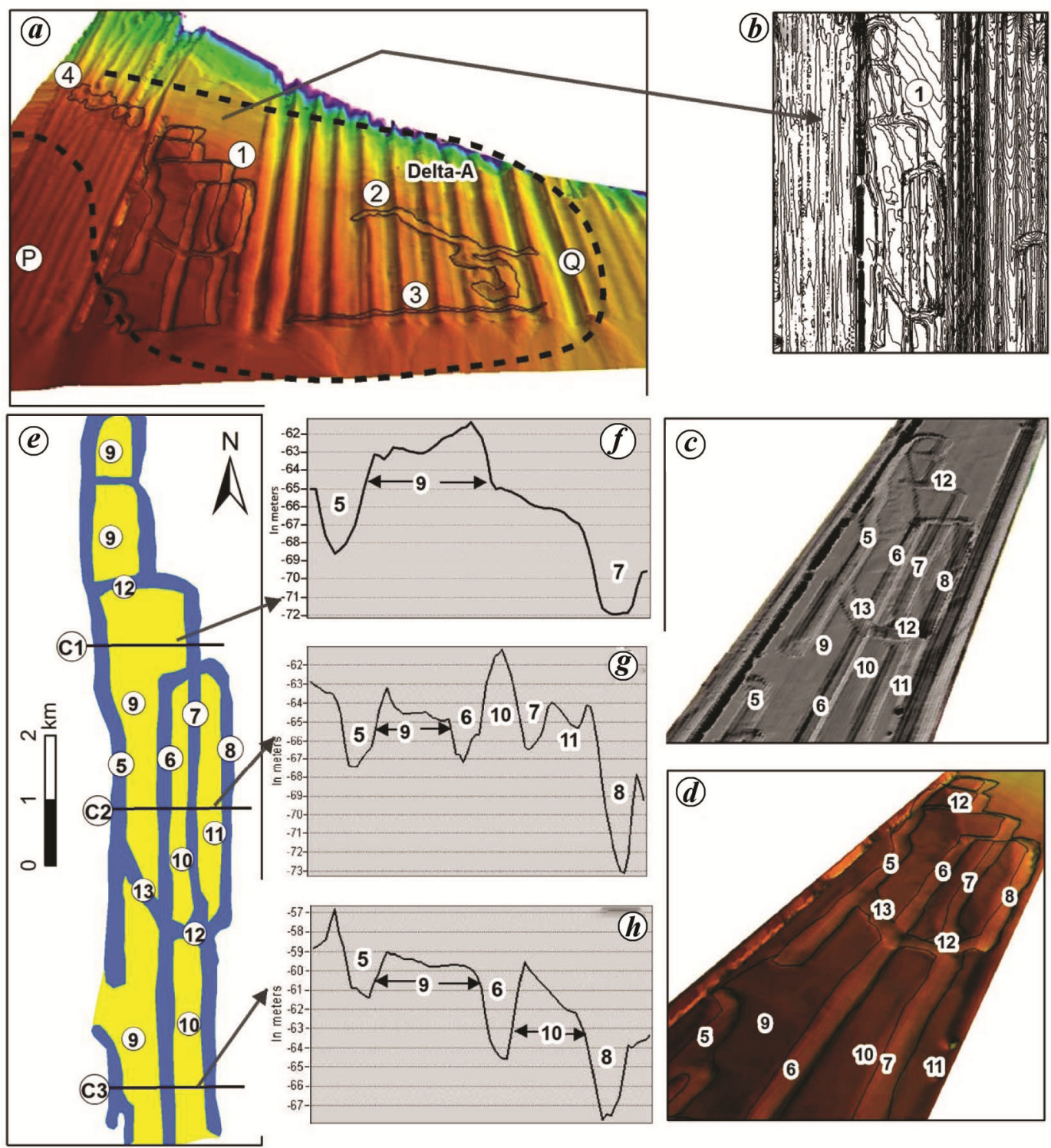

Figure 4. Anomaly no 1. a, Key map: colour-coded MBES-DEM data of seabed topography of delta-A area in the offshore region of Poompuhar. 1-4. b. Anomalous contour pattern of anomaly no. 1. $\boldsymbol{c}$, Shaded relief image of anomaly no. 1. $\boldsymbol{d}$, Colour-coded MBES-DEM data of anomaly 1. $\boldsymbol{e}$, North-south structure deduced from $\boldsymbol{a}-\boldsymbol{d}$. $\boldsymbol{f}$ - $\boldsymbol{h}$, Topographic profiles C1-C3 drawn across the north-south structure shown in $\boldsymbol{e}$ : (5-8) north-south-oriented linear depressions; (9-11) intervening elevated flat topography, (12) east-west depressions and (13) northwest-southeast depressions.

map (Figure $4 c$ ) and colour-coded DEM (Figure $4 d$ ) of MBES data. The overall assembly of these grids stands out as an anomaly amidst the corrugated contours and hence is marked as anomaly no. 1 ( 1 , Figure 2 and $4 b$ ). Anomaly no. 1 had a length of $11 \mathrm{~km}$ in north-south direction and breadth of $2 \mathrm{~km}$ in the east-west direction (Figure $4 e$ ). The topographic profiles drawn in the eastwest direction across anomaly no. $1(\mathrm{C} 1-\mathrm{C} 3$, Figure $4 e)$, show that these grids are bounded by north-southoriented, sub-parallel, narrow depressions (5-8, Figure $4 e$ ) and the intervening wider, flat-topped, elevated topography $(9-11$, Figure $4 e$ ). East-west and northwestsoutheast aligned depressions were found linking these north-south depressions (12 and 13, Figure $4 e$ ). While these depressions were 180-250 $\mathrm{m}$ wide and 4-7 $\mathrm{m}$ deep, the intervening flats were 500-2000 $\mathrm{m}$ wide and 5-12 high (Figure $4 f-h$ ). All these features indicate that the anomaly no. 1 may be a man-made structure.

Anomaly no 2: This is a northwest-southeast-oriented, $6 \mathrm{~km}$ long and 350-500-m wide feature showing welldefined near-linear contours in the MBES data (Figure $5 b$ ) and in the MBES colour-coded DEM (Figure $5 c$ ). Further, the topographic profile drawn along P1 shows its elevation as $2-3 \mathrm{~m}$ above the general seabed level (Figure $5 d$ ). Thus, it does not appear to be a natural feature and 

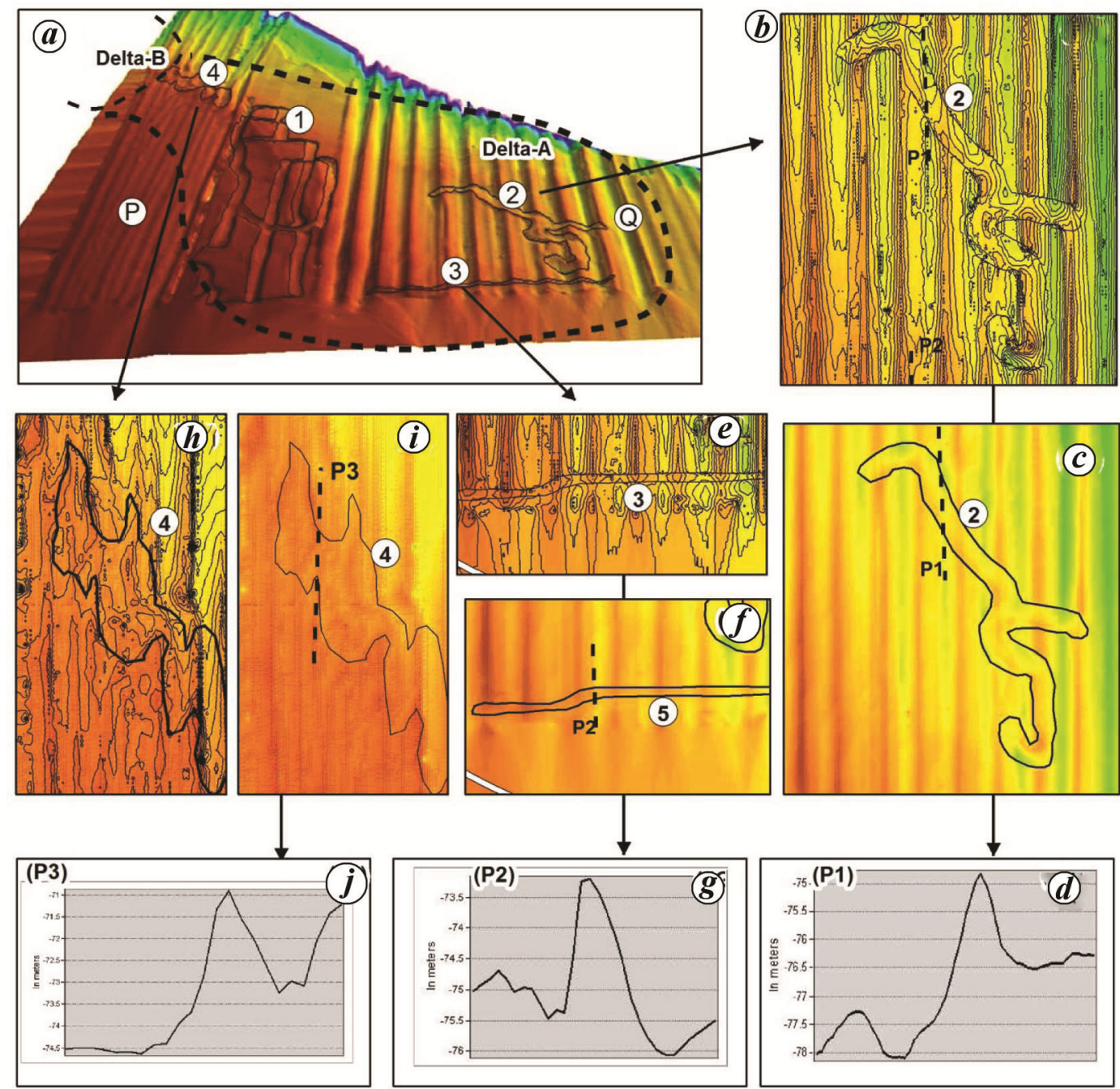

Figure 5. Anomaly nos 2-4. a, Key map: colour-coded MBES-DEM data of seabed topography of delta-A in the offshore region of a Poompuhar (1-4; see Figure 2). $\boldsymbol{b}$, Anomaly no. 2 shown by contours. $\boldsymbol{c}$, Colour-coded MBES-DEM and the north-south profile line (P1). $\boldsymbol{d}$, Topographic elevation of anomaly no. 2. e, East-west contour anomaly no. 3. $\boldsymbol{f}$, Colour-coded MBES-DEM and the north-south profile line (P2). $\boldsymbol{g}$, Topographic elevation of anomaly no. 3. $\boldsymbol{h}$, Anomaly no. 4 amidst the contours. $\boldsymbol{i}$, Colour-coded MBES-DEM data north-south profile line (P3), $\boldsymbol{j}$, North-south topographic elevation of anomaly no. 4 .

hence must be a man-made, ridge-like feature (P1, Figure $5 c$ and $d$ ).

Anomaly no 3: Anomaly no. 3 appears to be an eastwest elevated feature of $4 \mathrm{~km}$ length, as seen from the linear contours in the seabed (3, Figure $5 e$ ) and MBESDEM data $(5$, Figure $5 f)$. The $\mathrm{N}-\mathrm{S}$ profile drawn across it (P2, Figure 5f) shows its elevation as $1.5-2.0 \mathrm{~m}$ (Figure $5 \mathrm{~g}$ ). Since it was an isolated feature, anomaly no. 3 also may not be a natural structure.

Anomaly no. 4: The anomalous NW-SE contours shown by the MBES data in the midst of well-defined package of sub-parallel N-S MBES contours (4, Figures 2 and $5 \mathrm{~h}$ ) and the MBES-DEM data (Figure $5 i$ ), and the topographic profile drawn in the north-south direction (P3,
Figure $5 i$ and $j$ ) show that it is a north northwest-south southeast elevated feature of 3-4 m. The morphology and the geo-position of anomaly no. 4 indicate that this also may not be natural feature.

\section{Discussion and conclusion}

In the context of the morphology explained under Anomaly no-1 (anomalous contours) above it can be surmised that these depressions may be man-made canals/ waterways and the flat-topped topography may be of lands for habitation. These lead to the surmise that the anomaly no. 1 may be an ancient harbour of Poompuhar $11 \mathrm{~km}$ long in the north-south direction and 1-2 km wide in the east-west direction. The wider canals might have 


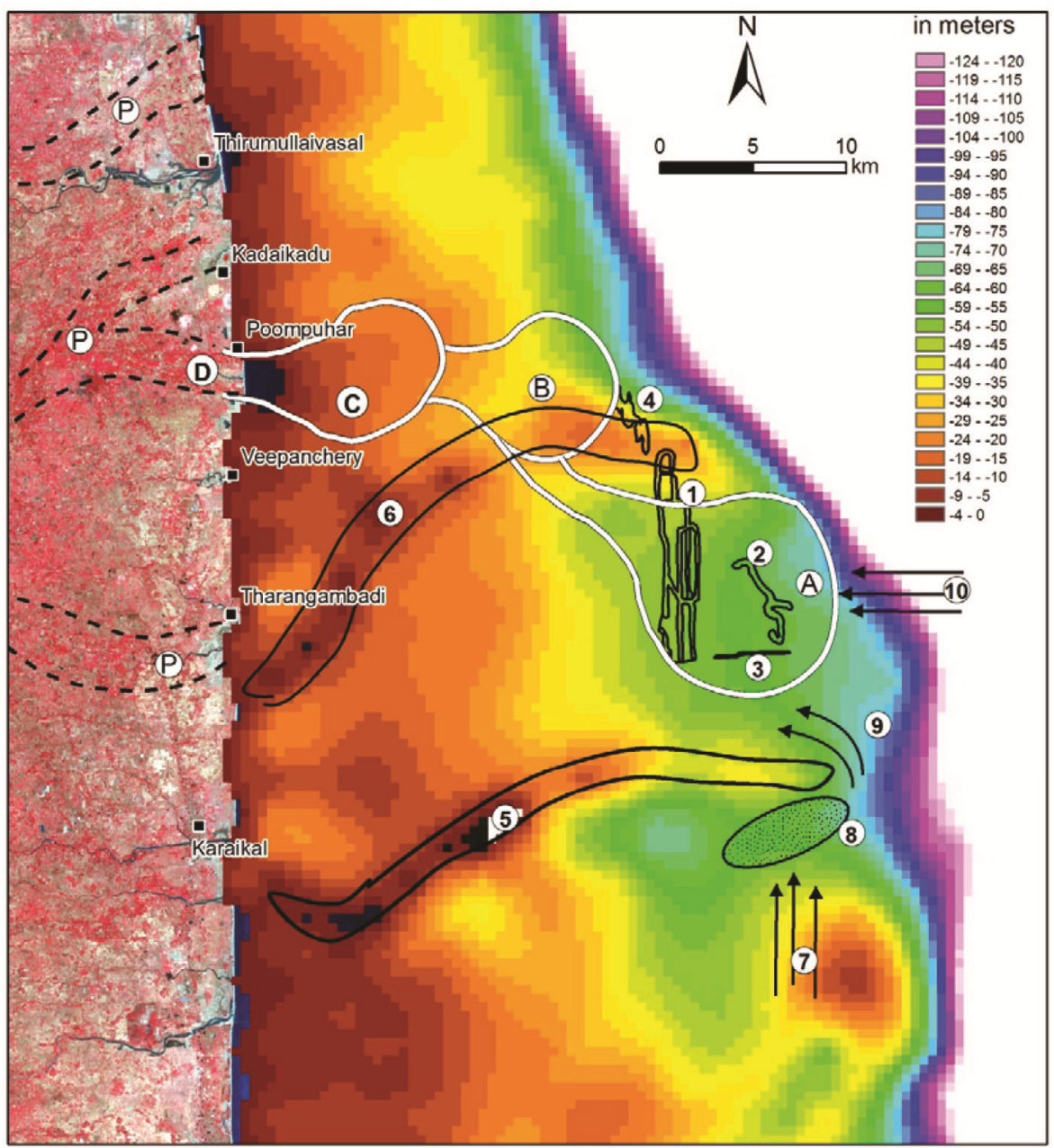

Figure 6. GEBCO-DEM: (1-4) Harbour and related manmade structure, (5 and 6) submarine ridges, (7) northerly moving littoral currents, (8) sediments dumped by the currents, (9) deflected component of the littoral currents, and (10) waves and tides.

been dug for the movement of bigger vessels and the narrow ones for smaller vessels and boats. The east-west and northwest-southeast depressions might have been dug for providing inter-connectivity between the long north-south canals, the turning of vessels and for the distribution, unloading and loading of merchandise. The geo-position of the said feature on the western wave and tide shadow slope of the delta-A region (10, Figure 6) further confirms that it must have been a harbour.

The north northwest-south southeast aligned anomaly no. 2 is a ridge with $2-3$ m elevation. Its shapeless pattern shows that it is not a natural feature like ancient beach ridges or any other geomorphic features of land-ocean interactive dynamics. So, it may be a man-made seawall built to protect the harbour from waves and storm surges (10, Figure 6). Anomaly no. 3 is again an east-west aligned ridge of 1.5-2.0 $\mathrm{m}$ height from the delta topography. This is located to the south of the seawall (anomaly no. 2, Figure 6) and southeast of the harbour (anomaly no. 3, Figure 6). Further, there was a near east-west trending submarine ridge south of the harbour (5, Figure 6 ). The littoral currents of the east coast of India move from south to north during nine months (February to October) and towards southerly during the remaining three months in a year ${ }^{24,25}$. These currents when obstructed by any natural or man-made projections, will dump the sands to the south of such projections and the deflected components of the currents will hit the coast/structures located to the north of it and cause erosion, as observed in several parts along the east coast of India ${ }^{25,26}$. The dynamics of the littoral current pattern in the past might have been similar. The violent and northerly-moving littoral currents on obstruction by the above ridge might have dumped the sediments to the south of the ridge, and the deflected components might have caused erosion of the harbour (Figure 6). So, the ancient people might have built the east-west seawall (3, Figure 6) to the southeast of the harbour to protect it from erosion. A study on the tectonics of the Cauvery delta showed several east-west trending faults acting as pathways for the creeks ${ }^{27,28}$. 
However, in this case, since anomaly no. 3 occurred as a single and isolated feature (3, Figure 6$)$, the probability of a fault is less and further, it has an elevation of $2 \mathrm{~m}$. Hence, it is a seawall constructed by ancient people to protect the harbour from erosion (1, Figure 6). The geographical location of the harbour from the regional geodynamic perspective also confirms this, since it is found between the two near easterly ridges, one in the south and the other in the north (5 and 6 respectively, Figure 6).

Anomaly no. 4 is a wavy north-northwest to southsoutheast-oriented ridge with a height of 2-3 m. Since it connects delta-A and delta-B between which some depressions are present, it might have been an earthen bridge constructed by the ancient people (4, Figure 6 ) either for regular movement or for shifting towards delta$\mathrm{B} /$ Poomphuar-II when the sea level was rising and Poompuhar-I had started submerging in the east due to rise in sea level.

Thus the study reveals that the four anomalies detected from MBES-DEM data/contours must be related to the ancient harbour and associated structures. These might have been constructed by the ancient people around $11,000-15,000$ years ago, as these are located in delta-A which falls in between the shorelines of the above period

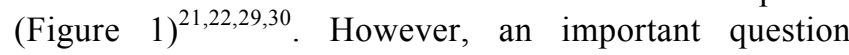
before us is whether ancient people had the knowledge and technology to construct such establishments. A number of harbours with similar pattern and layout have been located around the world, viz. Phoenician city, Tuni$\mathrm{sia}^{31,32}$, ancient harbour of Neapoli ${ }^{33-35}$; ancient harbour Pisa, Italy ${ }^{3,36}$; Nan-Madol offshore ancient city ${ }^{37}$; rivermouth harbours such as Nahariya, Tel Achziv; Tel Akko of Israel coast ${ }^{1,38,39}$; Magnus Portus, Alexandria ${ }^{5,40}$; ancient harbours of King Louis IX (Aigues-Mortes, Rhone Delta, France $)^{41}$ and the Harappan port at Lothal ${ }^{42,43}$. Among these, the Harappan port and the Nan-madol offshore ancient city and its gridded land parcels bounded by waterways $^{37}$ typically resemble the present harbour identified as anomaly no. 1 in the delta-A region. All of them in general belong to 2000-6000 years BP. Thus, this technology might have been transferred from Poompuhar to other parts of the world. This, requires further studies using advanced tools like single beam and MBES data, underwater profiler survey, underwater optical and sonar photography, and their processing.

1. Morhange, C. et al., Geoarchaeological evolution of Tel Akko's ancient harbour (Israel). J. Archaeol. Sci. Rep., 2016, 7, 7181.

2. Henderson, J. C., Gallou, C., Flemming, N. C. and Spondylis, E., The Pavlopetri Underwater Archaeology Project: investigating an ancient submerged town. In Underwater Archaeology and the Submerged Prehistory of Europe, Oxbow Books, Oxford, England, 2011, pp. 207-218.

3. Allinne, C., Morhange, C., Pasquinucci, M. and Roumieux, C., Géoarchéologie des ports de Pise «Stazione Ferroviaria San Rossore» et de Portus Pisanus. Dynamiques géomorphologiques, sources antiques et données archéologiques. Rev. Archéol. Narbonn., 2016, 44, 321-338.

4. Goddio, F., Topography and Excavation of Heracleion-Thonis and East Canopus (1996-2006): Underwater Archaeology in the Canopic Region in Egypt, Institute of Archaeology, University of Oxford, UK, 2007, p. 137.

5. Goddio, F., The BP exhibition Sunken Cities: Egypt's lost worlds at the British Museum. Arts Asia, 2016, 46(6), 148-156.

6. Flaux, C., El-Assal, M., Marriner, N., Morhange, C., Rouchy, J. M., Soulié-Märsche, I. and Torab, M., Environmental changes in the Maryut lagoon (northwestern Nile delta) during the last $\sim 2000$ years. J. Archaeol. Sci., 2012, 39(12), 3493-3504.

7. Galili, E., Rosen, B., Zviely, D., Silberstein, N. A. and Finkielsztejn, G., The evolution of Akko harbor and its Mediterranean maritime trade links. J. Island Coast Archaeol., 2010, 5(2), 191-211.

8. Fouache, E., Kelterbaum, D., Brückner, H., Lericolais, G., Porotov, A. and Dikarev, V., The Late Holocene evolution of the Black Sea - a critical view on the so-called Phanagorian regression. Quaternary Int., 2012, 266, 162-174.

9. Schottenhammer, A., The 'China Seas' in world history: a general outline of the role of Chinese and East Asian maritime space from its origins to c. 1800. J. Mar. Island Cult., 2012, 1(2), 63-86.

10. Rao, S. R., Excavation of the legendary city of Dwarka in the Arabian Sea. J. Mari. Archaeol., 1990, 1, 59-98.

11. Rao, S. R., Rao, T. C., Gaur, A. S., Sila Tripati, Sundaresh and Gudigar, P., Underwater Explorations off Poompuhar 1993. J. Mari. Archaeol., 1993, 5-6, 7-22.

12. Pillay, K. K., History of Tamil Nadu: her People and Culture, Tamil Nadu Textbook Society, 1977.

13. Nilakanta Sastri, K. A., The Cholas, Madras University Historical Series No. 9, 1935, 1, 36-73.

14. Ramachandran, C. E., Ahananuru in its Historical Setting, University of Madras Publications, Madras, 1974, p. 149.

15. Pillai, R. S., Cilappatikaram, Tamil University Publications, Thanjavur, 1989, p. 150.

16. Vora, K. H., A note on geophysical explorations for marine archaeology off Tamil Nadu coast, India. Int. J. Naut. Archaeol., 1987, 16(2), 159-164.

17. NIO, Marine archaeological explorations in Poompuhar waters. National Institute of Oceanography, Goa, Technical Report no. NIO/SP/13/95\&97, 1995, 1997.

18. Athiyaman, N., Two wharves at Poompuhar: a technical study. Paper presented at the Second International Conference on Marine Archaeology, Thane, India, 1999, pp. 8-10.

19. Jayakumar, S., Gaur, A. S., Chandramohan, P. and Jena, B. K., Submergence of Poompuhar - study based on underwater explorations and coastal processes. In Proceeding Volume of Third Indian National Conference on Harbour and Ocean Engineering (INCHOE-2004), National Institute of Oceanography (NIO), Goa, India, 2004, vol. 2, pp. 820-832.

20. Hancock, G., Underworld: The Flooded Kingdoms of the Ice Age, Penguin Books, London, 2002, vol. 112, p. 741.

21. Ramasamy, S. M., Saravanavel, J., Kumanan, C. J. and Gunasekaran, S., Coordinates and chronology of the ancient port city of Poompuhar, South India. Curr. Sci., 2017, 112(6), 1112-1115.

22. Fleming, K., Johnston, P., Zwartz, D., Yokoyama, Y., Lambeck, K. and Chappell, J., Refining the eustatic sea-level curve since the Last Glacial Maximum using far-and intermediate-field sites. EPLS, 1998, 163(1-4), 327-342.

23. Lillesand, T., Kiefer, R. W. and Chipman, J., Remote Sensing and Image Interpretation, John Wiley, New York, 2015.

24. Sambasiva Rao, M., Morphology and evolution of modern Cauvery delta, Tamil Nadu, India. Trans Inst Indian Geogr., 1982, 4, 68-78.

25. Ramasamy, S. M., Remote sensing and active tectonics of South India. Int. J. Remote Sensing, 2006, 27(20), 4397-4431. 
26. Ramasamy, S. M., Holocene tectonics revealed by Tamil Nadu deltas, India. J. Geol. Soc. India, 2006, 67(5), 641.

27. Elliott, C. I., Joyce, E. B., Bishop, I., Ramasamy, S. M. and Kumanan, C. J., Lineaments of southeastern India and their relationship to drainage pattern and groundwater flow. In Proceeding Volume on International Association of Hydrogeologists, University of Melbourne, Melbourne, 1998, pp. 131-135.

28. Ramasamy, S. M., Kumanan, C. J., Saravanavel, J. and Selvakumar, R., Geosystem responses to 26 December 2004 tsunami and mitigation strategies for Cuddalore-Nagapattinam coast, Tamil Nadu. India. J. Geol. Soc. India, 2006, 68(6), 967.

29. Rana, S. S., Nigam, R. and Panchang, R., Relict benthic foraminifera in surface sediments off central east coast of India as indicator of sea level changes. Indian J. Marine Sci., 2007, 36, 355360 .

30. Loveson, V. J. and Nigam, R., Reconstruction of Late Pleistocene and Holocene sea level curve for the east coast of India. J. Geol. Soc. India, 2019, 93(5), 507-514.

31. Chelbi, F., Paskoff, R. and Trousset, P., La baie d'Utique et son évolution depuis l'Antiquité: une réévaluation géoarchéologique. Antiq. Africaines, 1995, 31(1), 7-51.

32. Delile, H. et al., The geoarchaeology of Utica, Tunisia: the paleogeography of the Mejerda Delta and hypotheses concerning the location of the ancient harbor. Geoarchaeology, 2015, 30(4), 291306.

33. Giampaola, D. et al., La scoperta del porto di Neapolis: dalla ricostruzione topografica allo scavo e al recupero dei relitti. Archeol. Marittima Mediterr., 2006, 2, 48-91.

34. Carsana, V., Febbraro, S., Giampaola, D., Guastaferro, C., Irollo, G. and Ruello, M. R., Evoluzione del paesaggio costiero tra Parthenopee Neapolis. Méditerranée. Rev. Géogr. Médit. J. Meditary. Geogr., 2009, 112, 14-22.

35. Di Donato, V. et al., Development and decline of the ancient harbor of Neapolis. Geoarchaeology, 2018, 33(5), 542-557.

36. Benvenuti, M., Mariotti-Lippi, M., Pallecchi, P. and Sagri, M., Late-Holocene catastrophic floods in the terminal Arno River
(Pisa, Central Italy) from the story of a Roman riverine harbour. Holocene, 2006, 16(6), 863-876.

37. McCoy, M. D., Alderson, H. A., Hemi, R., Cheng, H. and Edwards, R. L., Earliest direct evidence of monument building at the archaeological site of Nan Madol (Pohnpei, Micronesia) identified using ${ }^{230} \mathrm{Th} / \mathrm{U}$ coral dating and geochemical sourcing of megalithic architectural stone. Quaternary Res., 2016, 86(3), 295-303.

38. Giaime, M., Morhange, C., Marriner, N., López-Cadavid, G. I. and Artzy, M., Geoarchaeological investigations at Akko, Israel: new insights into landscape changes and related anchorage locations since the Bronze Age. Geoarchaeology, 2018, 33(6), 641-660.

39. Anthony, E. J., Shore Processes and their Palaeoenvironmental Applications, Elsevier, 2008.

40. Goddio, F. and Yoyotte, J., The Portus Magnus of Alexandria. In Egypt's Sunken Treasures (ed. Goddio, F.), Prestel, London, UK, 2008, 2nd edn.

41. Rey, T., Faucherre, N., Virmoux, C. and Galano, L., Paleoenvironmental reconstruction of the ancient harbors of King Louis IX (Aigues-Mortes, Rhone Delta, France). J. Archaeol. Sci. Rep., 2016, 9, 505-513.

42. Leshnik, L. S. and Junghans, K. H., The Harappan 'port' at Lothal: Another View 1. Am. Anthropol., 1968, 70(5), 911-922.

43. Rao, S. R., Lothal, A Harappan Port Town, Vol. II, Memoirs of the Archaeol. Surv. of India, New Delhi, 1985.

ACKNOWLEDGEMENTS. We thank the ICPS Division, Department of Science and Technology, Government of India, for providing funds through a project 'digital reconstruction of ancient port city Poompuhar', under which the present study was carried out.

Received 21 November 2019; revised accepted 18 May 2020

doi: $10.18520 / \mathrm{cs} / \mathrm{v} 119 / \mathrm{i} 3 / 526-534$ 